\title{
LOOKING FOR A BETTER QUALITY OF LIFE: CHARACTERISTICS AND EXPECTATIONS OF AUSTRALIANS ON A WAITLIST FOR A HEARING ASSISTANCE DOG
}

Contributions:

B Study design/planning

C Data analysis/statistics

C Data analysis/statistics

D Data interpretation

E Preparation of manuscrip

F Literature analysis/search

$\mathrm{G}$ Funds collection

\author{
Jordan Drewitt Smith ${ }^{1, C-F}$, Carlie Driscoll ${ }^{1, A-F}$, Nancy A Pachana ${ }^{2, A, D-F}$ \\ ${ }^{1}$ School of Health \& Rehabilitation Sciences, University of Queensland, Australia \\ ${ }^{2}$ School of Psychology, University of Queensland, Australia
}

Corresponding author: Carlie Driscoll, School of Health \& Rehabilitation Sciences, University of Queensland, 4072, Brisbane, Australia; email: carlie.driscoll@uq.edu.au, Phone: +61733653095

\begin{abstract}
Background: Hearing assistance dogs not only alert their hearing-impaired owners to environmental sounds but may also improve their quality of life. Unfortunately, audiologists rarely recommend this service, potentially due to a dearth of associated literature. This study explores the demographic and audiological characteristics, general health, socio-emotional functioning, and expectations of persons seeking a hearing dog.

Material and methods: This prospective cohort study of 23 respondents from the 2019 Australian Lions hearing dog waitlist utilized a written survey method.

Results: Respondents were predominately female (78\%), financially stable (91\%), had previous pet ownership experience (91\%), a self-reported severe/profound sensorineural hearing loss (92\%), and were regular hearing device users (87\%). Respondents reported substantial social and emotional limitations. Overall, the health function of respondents was below that of the general population. Social function was also comparatively impaired. Most respondents strongly agreed that the hearing dog should be "a companion" and "a living thing to love."

Conclusions: Respondents were demographically varied but were regular hearing-device users, with significant social, emotional, and health limitations. In addition to being alerted to environmental sounds, respondents expected the hearing dog to serve a broad socio-emotional function.
\end{abstract}

Key words: • health • social functioning • hearing loss • expectations • emotional functioning • Hearing Assistance Dogs

POPRAWA JAKOŚCI ŻYCIA: CECHY I PRAGNIENIA AUSTRALIJCZYKÓW, KTÓRZY SĄ NA LIŚCIE OCZEKUJĄCYCH NA PSA ASYSTENTA OSOBY NIEDOSŁYSZĄCEJ

\section{Streszczenie}

Wstęp: Pies asystent nie tylko ostrzega swojego niedosłyszącego właściciela o dźwiękach otoczenia, lecz także może poprawić jego jakość życia. Niestety audiolodzy rzadko polecają tę usługę, prawdopodobnie ze względu na brak odpowiedniej literatury. Niniejsze badanie dotyczy cech demograficznych i audiologicznych, ogólnego stanu zdrowia, funkcjonowania społeczno-emocjonalnego i pragnień osób oczekujących na psa asystenta.

Materiał i metody: W prospektywnym badaniu kohortowym wzięło udział 23 respondentów, którzy są na liście oczekujących na przydzielenie psa asystenta osoby niedosłyszącej w 2019 r. z australijskiej fundacji Lions. Badanie polegało na wypełnieniu ankiety.

Wyniki: Respondentami były przeważnie osoby płci żeńskiej (78\%), stabilne finansowo (91\%), już wcześniej posiadające zwierzęta domowe (91\%), zgłaszające znaczny lub głęboki niedosłuch typu odbiorczego (92\%) i regularnie używające urządzeń wspomagających słuch (87\%). Respondenci zgłaszali znaczne ograniczenia społeczne i emocjonalne. Ogólnie stan zdrowia respondentów i ich umiejętności społeczne były poniżej przeciętnej. Większość respondentów zdecydowanie zgodziła się, że pies asystent powinien być „towarzyszem” i „żywą istotą do kochania”.

Wnioski: Respondenci byli zróżnicowani demograficznie, ale regularnie używali urządzeń wspomagających słuch, mieli istotne ograniczenia społeczne, emocjonalne i zdrowotne. Oprócz zwracania uwagi na dźwięki otoczenia, respondenci oczekiwali, że pies asystent będzie pełnił szeroką funkcję społeczno-emocjonalną.

Słowa kluczowe: zdrowie $\bullet$ funkcjonowanie społeczne $\bullet$ utrata słuchu $\bullet$ oczekiwania $\bullet$ funkcjonowanie emocjonalne $\bullet$ pies asystent osoby niedosłyszącej

\section{Background}

Approximately 1 in 7 Australians experience hearing loss [1]. These individuals frequently present with multiple co-morbidities, including depression, phobic and other anxiety disorders, nervous tension, and social isolation [1-2]. The presence of these co-morbidities may have significant negative ramifications on the individual's quality of life and ability to be a contributing member of society [1-2]. The heightened presence of co-morbidities in those with a hearing impairment places audiologists in an important position, as often they are the first point of contact for those with hearing concerns [3]. As a result, audiologists are trained in providing patient-centred care and 
rehabilitative options that extend beyond the diagnosis and management of hearing loss, to encompass an individual's daily living activities and social participation requirements, thus maximising an individual's ability to thrive personally and socially [3-4]. To accomplish individualised care, audiologists need to be aware of the multiple rehabilitative options available that can reduce the presence of co-morbidities and the consequences of hearing loss [3]. One such option that has been largely unexplored in the audiology literature is "hearing assistance dogs" or "hearing dogs".

Hearing dogs are professionally trained canines that assist persons with hearing impairment by alerting them to environmental sounds, such as the doorbell ringing, a smoke alarm going off, and other sounds relevant for safe independent living [5-6]. The Australian Lions Hearing Dogs is the primary hearing dog provider servicing Australians 18 years and older [5]. This organisation recruits and trains potential canine candidates and places them with owners. It also provides ongoing maintenance, support, and assessment [5]. However, hearing dogs provide more than just practical assistance to persons with hearing loss: From as early as the 1970s, they have been suggested to increase an individual's quality of life [7]. Additional benefits include the provision of companionship, security, stress reduction, and decreased anxiety [8-12]. Recently, Lundqvist et al. [12] found evidence that those with a hearing or service dog experience connections with their dog that positively impacted on their health-related quality of life, wellbeing, and activity level. The dogs were able to alleviate stress, increase owner independence, and decrease their risk of social isolation [12]. Although the study's findings were compelling, it is important to note that the very small sample size may have limited generalisability of the results. Unfortunately, most of the literature surrounding hearing dogs encounters the limitation of small sample size $[6,8-9,11-13]$, possibly reflecting the small population of individuals that own hearing dogs worldwide [14].

Nevertheless, societal beliefs support the existing literature and advocate for the benefits of hearing dogs. For example, researchers have capitalised on the benefits of hearing dogs to create conceptual models of "hearing-dog robots" that nudge their owners in response to pre-programmed environmental noises [14-15]. Although a unique concept, these robots have not yet been able to demonstrate the additional benefits associated with hearing dogs, such as companionship, stress reduction, reduced depression and anxiety, heightened self-esteem, and a general increase in quality of life $[8,10,12,16-18]$. These lived experiences are often considered to be more beneficial and more highly regarded for improving quality of life in hearing dog owners than the practical functionality provided by the dog [19-20]. For instance, one owner of a hearing dog reflected that "The most important thing Teddy does is make me feel like a useful member of society. I no longer feel like I'm on the outside looking in; I'm part of the world at last. I'm thankful beyond words to hearing dogs because Teddy has helped me discover life and who I really am - he's given me an identity, a purpose and made me complete" [17,p.16].

The association between ownership of hearing dogs and an increased quality of life confirms the necessity for audiologists to consider hearing dogs as a rehabilitative option for suitable clients. While the current literature briefly explores the benefits associated with hearing dogs, to date there have been no articles that investigate the characteristics and expectations of those on the waitlist for a hearing dog. Nor have there been any studies conducted from an audiological viewpoint, nor using modern measurement tools. As audiology is an evidence-based profession, this lack of knowledge concerning the clients who may want or need a hearing dog can discourage audiologists from recommending this option and, in turn, creates a barrier for the client in gaining targeted assistance that suits their needs and lifestyle requirements.

The purpose of this paper was to explore the demographics, audiological characteristics, health, socio-emotional function, and expectations of persons seeking a hearing dog in a current waitlist cohort, with an audiological and multidisciplinary view of health and wellbeing. It aimed to answer the practical concerns of: (1) which clients might desire a hearing dog, and (2) what do these hearing dog recipients expect to gain?

\section{Material and methods}

Ethical approval for the study was obtained from the University of Queensland Behavioural and Social Sciences Ethical Review Committee (approval number 2018002035).

\section{Study Design and Procedure}

This prospective study utilized a written survey method, targeting all individuals on the Australian Lions Hearing Dog waitlist. This method was employed as it directly and efficiently engaged the current waitlist population while allowing for anonymity and reflectiveness in responses [21].

Each participant was required to complete six questionnaires, selected to provide the broadest understanding of the characteristics and expectations of the hearing dog waitlist cohort from an audiological and multidisciplinary perspective of health and wellbeing, while remaining cognisant of the burden upon respondents. The questionnaires were provided to respondents in a "survey package" along with a Participant Information Form, Participant Consent Form, and a pre-paid, self-addressed return envelope. Individuals who wished to respond but were unable to complete their surveys via post were provided the option to participate via email or telephone. Respondents provided voluntary informed consent prior to engaging in the study and were advised of the ability to withdraw at any stage prior to result dissemination. The Australian Lions Hearing Dogs posted a generic reminder notice, via their social media and newsletter, approximately 3 weeks following initial dissemination of the survey packages.

\section{Respondents}

All individuals on the Australian Lions Hearing Dogs waitlist $(n=45)$ were invited by post to participate in the study. Surveys were collected from eligible respondents over a 5-month period, between January and May 2019. A total of 24 individuals elected to participate in the 
study, providing a response rate of 53\%. One participant later chose to withdraw, reducing the working database to 23 respondents. Demographics of the study cohort are presented in the Results section.

\section{Materials}

\section{General Information Survey}

This was an informal, predominantly closed-ended response survey, designed for the purposes of this study, and consisting of 11 questions that pertained to the general demographics of the respondents. Information required for completion is contained under an "About Me" section which included questions relating to the participant's gender, age, educational attainment, living environment/arrangement, employment status, current pets, and past hearing dog or pet ownership. An additional section, "Experiences with Your Hearing Dog," required completion if respondents had previously owned a hearing dog. This section contained three, open-ended questions which addressed positive and negative perceptions about having a hearing dog, and any changes that they would recommend. This survey provided demographical characteristics of the cohort with a view to contributing information on who desires a hearing dog.

\section{Hearing Information Survey}

This 10-question, largely closed-ended response survey requested audiological information from respondents, including type of hearing loss, degree of hearing loss, time with hearing loss, communication mode, membership of the Deaf community, and current and previous supports used. Additionally, there was an open comment section on the final question, "Which sounds do you want your hearing dog to help you with?", which contributed information on why recipients may want a hearing dog. Similar examples are widely used in audiological studies to gather patient-specific hearing information from a large population [22-23]. Additionally, respondents were requested to supply a copy of their current audiogram, to verify the type and degree of hearing loss reported in the survey.

\section{Hearing Handicap Inventory for the Elderly (HHIE) and Hearing Handicap Inventory for Adults (HHIA)}

Both questionnaires aimed to investigate the perceived emotional and social consequences of hearing loss that were not readily apparent from the audiogram. These closedended questionnaires consisted of 25 items (a 13-item emotional subscale and a 12 -item situational/social subscale) which concerned the activity limitations and participation restrictions of individuals from the viewpoint of the International Classification of Functioning, Disability, and Health (ICF) [24]. The HHIE contained specific questions regarding the impact of hearing loss within the aged population. The HHIA questionnaire was modified from the HHIE questionnaire to include questions and likely concerns regarding the impact of hearing loss that were relevant to adults under 65 years of age [25]. In the present study, participant age determined which of the two questionnaires required completion.
These measures were selected for their sound psychometric properties: high test-retest reliability (exceeding 0.8 ), high internal consistency of questions, and a low standard error of measurement in adult populations [24-28], as well as their brevity and ease of administration/interpretation. Both are commonly-used, self-report instruments found in audiological clinical practice and research. They contributed information, from a broad ICF perspective, on who desires a hearing dog and insight into why.

Response categories for each item included: Yes; Sometimes; No, with points awarded 4, 2, and 0, respectively. Total scores ranged from 0 to 100 , and higher scores indicated greater perceived limitations and restrictions.

\section{Medical Outcomes Survey (MOS)}

Due to its ease of scoring, a specific version of the MOS - the RAND 36-item Health Survey (v.1.0) [29] - was employed in this study. It includes 11 questions, with 36 sub-items in total, related to an individual's current and previous health abilities and restrictions. Responses were provided in a forced-choice, ordinal-scale format, with response direction and categories varying with each question. The items of the survey provided eight scaled scores (ranging from 0 to 100) that were weighted sums of the questions in each section (Physical functioning; Role limitations due to physical health; Role limitations due to emotional problems; Energy/fatigue; Emotional wellbeing; Social functioning; Pain; General health). A total score was obtained by averaging the scores of the eight scales, with higher scores indicating better health/less disability.

This questionnaire is applicable to the current study due to its development for self-administered use in research and general population surveys, for respondents 14 years or older [29]. Furthermore, it has high validity and reliability $(>0.9)$ in assessing the comprehensive physical and mental components of an individual's health status [29]. The responses collected from the MOS provided information on who desires a hearing dog.

\section{Social Functioning Questionnaire (SFQ)}

This instrument contained seven questions which measured an individual's ability to function within society. It covered the essential aspects of work and home tasks, financial concerns, relationships with family, social contacts, and leisure activities. In view of the study cohort's age, one question from the 8-item original survey that addressed sexual activities was not included. Responses were provided in a 4-point Likert-type scale (most of the time; quite often; sometimes; not at all). Total scores ranged from 0 to 21 points. A total score of 9 or more is typically indicative of poor social functioning (equivalent to a 10 or higher on the original survey). Within the general population, a mean score of 4.6 is expected and only $10 \%$ will display scores of $\geq 10$ [30].

This questionnaire was selected for its ability to provide a quick assessment of perceived social functioning, as distinguished from other self-rating measures of health [30], along with its robust psychometric characteristics [30-31]. This instrument can be used for large samples and 
has demonstrated a good correlation between its score and the quality of life of the individual [30]. The SFQ was used to determine who desires a hearing dog from a whole person and societal viewpoint.

\section{Pet Expectations Inventory (PEI)}

This measure was based on George's Pet Expectations Inventory, which was a questionnaire developed to inform industry on the roles that pets are expected to play in their owners' lives [32]. It was adapted for this study to provide questions relating to the role that potential owners expect the hearing dog to play in their lives (see Appendix). Each participant was required to complete 13 questions, giving responses in a 7-point Likert scale from "strongly agree" to "strongly disagree." Total scores range from 13 to 91 points. Higher scores suggest that the responder expects the hearing dog to serve a much broader role than simply to assist with the hearing of environmental sounds. The responses collected provided information on why the recipient required a hearing dog, in terms of experiential expectations.

\section{Analysis of Data}

All data were initially entered into a database using Microsoft Excel and, later, cleaned and analysed using IBM SPSS Statistics version 26. Analysis of data involved a mixed methods approach. Quantitative data were analysed using a combination of descriptive and correlational methods in accordance with the nature of the data supplied by the various questionnaires. Responses to any open-ended questions were transcribed verbatim for analysis.

\section{Results}

\section{Demographical Characteristics}

Regarding age distribution, $43 \%$ of respondents were under 65 years of age and $52 \%$ were 65 years or older, with a mean age of 62.6 years $(\mathrm{SD}=14.7, \mathrm{Mdn}=66.0$, range: $25-88)$. Respondents were predominantly female (78\%), retired (70\%), and either married $(26 \%)$ or widowed $(26 \%)$. Most respondents lived alone $(57 \%)$, in a house $(87 \%)$, and owned their own property $(70 \%)$. The highest form of education attained was mainly college/TAFE (35\%) or university (30\%). Almost all of the respondents had previously owned a pet (91\%), though $87 \%$ had never owned a hearing dog. Over half of respondents did not currently own a pet (52\%). Complete demographical characteristics of respondents are summarised in Table 1.

Previous owners $(n=2,9 \%)$ could elect to answer the open-ended "Experiences with Your Hearing Dog" section of the questionnaire. Responses from the two owners are transcribed verbatim below. In response to positive perceptions about having a hearing dog:

"Best friend, inquisitive bystander, doesn't argue back." "Felt secure, company, very helpful."

In response to negative perceptions about having a hearing dog:

"Can't visit people if animals not allowed inside, leaving (dog at) home for Dr/Dentist appointment."

\section{"None."}

In response to changes they would recommend: "Public awareness, stigma."

\section{Audiological Characteristics}

The majority of respondents self-reported a sensorineural hearing loss (39\%), 17\% a mixed hearing loss, and $9 \%$ a conductive hearing loss. However, $26 \%$ were unsure of the type of their hearing loss. Most respondents reported a severe degree of loss $(48 \%)$, with $44 \%$ having a profound loss. The hearing loss was most frequently reported to have been gradually acquired (52\%), followed by present at birth (30\%). Respondents mostly communicated orally (78\%) and were not members of the Deaf community (78\%). All respondents had previously used hearing aids $(100 \%)$, with over half also having previously used assistive listening devices (ALDs, 57\%). Hearing aids were currently used by $74 \%$ of respondents, cochlear implants by $30 \%$. Devices were worn for over $12 \mathrm{~h}$ daily by $61 \%$ of users, followed by $7-12 \mathrm{~h}$ a day by $26 \%$. A total of $71 \%$ of wearers reported their device to be "useful" or "very useful." Complete audiological characteristics of respondents are summarised in Table 2.

Most respondents desired their hearing dog to assist with the sound of a door-knock (96\%). The remaining sounds required for assistance, from most reported to least reported, included: the sound of the doorbell (91\%), smoke alarm (91\%), mobile phone (83\%), house phone (65\%), getting another person (65\%), alarm clock (52\%), oven timer (48\%), kettle whistle (22\%), and baby cry (13\%). Additional sounds given by five respondents in the open-ended "other" category are transcribed verbatim below:

"Break in."

"Fridge alarm, noises from behind."

"Hearing aid whistle, respiratory machine."

"Police, ambulance sirens."

"Station sounds."

\section{Hearing Handicap Inventory for the Elder- ly (HHIE) / Hearing Handicap Inventory for Adults (HHIA)}

The HHIE and HHIA questionnaires are scored from 0 to 100 . The higher the score, the greater the perceived limitation. The median total score for the HHIE was $58(n=13$, range 30-74), with an emotional subscale median score of 30 (range 10-38), and a situational/social subscale median score of 32 (range 18-42).

The median total score for the HHIA was $79(n=10$, range 26-98), with an emotional subscale median score of 43 (range 6-52), and a situational/social subscale median score of 39 (range 14-46).

\section{Medical Outcomes Survey (MOS)}

Table 3 outlines the mean, median, and standard deviations for the subscales of: Physical functioning; Role limitations due to physical health; Role limitations due to emotional problems; Energy/fatigue; Emotional wellbeing; Social 
functioning; Pain; General health, and total score, as compared to Australian normative data, and ranked from the most severe to least severe subscale scores. The lower the score, the more severe the health impairment in that category. The mean total score for the MOS was $65.6(\mathrm{Mdn}=66.9$, $\mathrm{SD}=15.2$, range 43.6-87.5). The most severe health impairment reported by respondents was Energy/fatigue, with the least severe health impairment being Emotional wellbeing. However, care must be taken when interpreting results, due to the large standard deviations.

\section{Social Functioning Questionnaire (SFQ)}

Table 4 contains subscale scores listed from most severe to least severe impairment.

The total SFQ mean score for the 22 respondents was $6.5(\mathrm{Mdn}=6.5, \mathrm{SD}=3.7$, range $1-15)$, with $32 \%$ of respondents scoring $\geq 9$. Close relationship difficulties and feeling lonely and isolated from others were the most severely rated social functioning parameters, with enjoyment of spare

Table 1. Demographic characteristics of an Australian hearing dogs waitlist cohort $(n=23)$

\begin{tabular}{|c|c|}
\hline Characteristics & $n(\%)$ \\
\hline \multicolumn{2}{|l|}{ Gender } \\
\hline Male & $5(21.7)$ \\
\hline Female & $18(78.3)$ \\
\hline \multicolumn{2}{|l|}{ Age } \\
\hline$<65$ years & $10(43.4)$ \\
\hline$\geq 65$ years & $12(52.2)$ \\
\hline Missing data & $1(4.3)$ \\
\hline \multicolumn{2}{|l|}{ Marital Status } \\
\hline Single & $3(13.0)$ \\
\hline Partnered & $1(4.3)$ \\
\hline Married & $6(26.1)$ \\
\hline Separated & $1(4.3)$ \\
\hline Divorced & $4(17.4)$ \\
\hline Widowed & $6(26.1)$ \\
\hline Missing data & $1(4.3)$ \\
\hline \multicolumn{2}{|l|}{ Education Completed } \\
\hline Primary School & $2(8.7)$ \\
\hline High School & $5(21.7)$ \\
\hline College/TAFE & $8(34.8)$ \\
\hline University & $7(30.4)$ \\
\hline Missing data & $1(4.3)$ \\
\hline \multicolumn{2}{|l|}{ Living Arrangement } \\
\hline Partner & $3(13.0)$ \\
\hline Children & $2(8.7)$ \\
\hline Partner and children & $3(13.0)$ \\
\hline Other family & $1(4.3)$ \\
\hline Friends & $0(0)$ \\
\hline Flatmate & $0(0)$ \\
\hline Alone & $13(56.5)$ \\
\hline Missing data & $1(4.3)$ \\
\hline \multicolumn{2}{|l|}{ Accommodation } \\
\hline House & $20(87.0)$ \\
\hline Unit & $3(13.0)$ \\
\hline Townhouse & $0(0)$ \\
\hline
\end{tabular}

\begin{tabular}{|c|c|}
\hline Characteristics & $n(\%)$ \\
\hline \multicolumn{2}{|l|}{ Home Owner } \\
\hline Owned & $16(69.6)$ \\
\hline Mortgaged/home loan & $3(13.0)$ \\
\hline Government housing & $1(4.3)$ \\
\hline Rent & $1(4.3)$ \\
\hline Family & $1(4.3)$ \\
\hline Caretaker & $1(4.3)$ \\
\hline \multicolumn{2}{|l|}{ Employment } \\
\hline Full-time & $2(8.7)$ \\
\hline Part-time & $3(13.0)$ \\
\hline Casual & $1(4.3)$ \\
\hline Unemployed & $1(4.3)$ \\
\hline Retired & $16(69.6)$ \\
\hline \multicolumn{2}{|l|}{ Previous Pet Ownership } \\
\hline Yes & $21(91.3)$ \\
\hline No & $2(8.7)$ \\
\hline \multicolumn{2}{|l|}{ Previous Hearing Dog Ownership } \\
\hline Yes & $2(8.7)$ \\
\hline No & $20(87.0)$ \\
\hline Missing data & $1(4.3)$ \\
\hline \multicolumn{2}{|l|}{ Current Pets } \\
\hline Cat & $1(4.3)$ \\
\hline Cat and Other & $1(4.3)$ \\
\hline Bird & $3(13.0)$ \\
\hline Chicken & $1(4.3)$ \\
\hline Chicken and Fish & $1(4.3)$ \\
\hline Fish & $1(4.3)$ \\
\hline Other & $1(4.3)$ \\
\hline Unspecified & $1(4.3)$ \\
\hline None & $12(52.2)$ \\
\hline Missing Data & $1(4.3)$ \\
\hline
\end{tabular}


Table 2. Audiological characteristics of an Australian hearing dogs waitlist cohort $(n=23)$

\begin{tabular}{|c|c|c|c|}
\hline Characteristics & $n(\%)$ & Characteristics & $n(\%)$ \\
\hline \multicolumn{2}{|l|}{ Type of Hearing Loss } & \multicolumn{2}{|l|}{ Current Supports Used } \\
\hline Sensorineural & $9(39.1)$ & Hearing aids & $17(73.9)$ \\
\hline Conductive & $2(8.7)$ & Cochlear implant & $7(30.4)$ \\
\hline Mixed & $4(17.4)$ & Hearing loss support group & $0(0)$ \\
\hline Don't know/unsure & $6(26.1)$ & Communication training & $2(8.7)$ \\
\hline Missing data & $2(8.7)$ & Assistive listening devices & $11(47.8)$ \\
\hline \multicolumn{2}{|l|}{ Degree of Hearing Loss } & Other & $1(4.3)$ \\
\hline Severe & $11(47.8)$ & \multicolumn{2}{|l|}{ Daily Use of Hearing Aid/Cochlear Implant } \\
\hline Profound & $10(43.5)$ & 0 hours & $1(4.3)$ \\
\hline Don't know/unsure & $2(8.7)$ & $1-2$ hours & $1(4.3)$ \\
\hline \multicolumn{2}{|l|}{ Duration of Hearing Loss } & $3-6$ hours & $1(4.3)$ \\
\hline Present since birth & $7(30.4)$ & $7-12$ hours & $6(26.1)$ \\
\hline Gradual over time & $12(52.2)$ & $>12$ hours & $14(60.9)$ \\
\hline Post-lingual paediatric & $1(4.3)$ & \multicolumn{2}{|c|}{ Usefulness of Hearing Aids/Cochlear Implants } \\
\hline Sudden due to illness/trauma & $3(13.0)$ & Not useful at all & $1(5.9)$ \\
\hline \multicolumn{2}{|l|}{ Communication Mode } & A little bit useful & $4(23.5)$ \\
\hline Oral (speech) only & $18(78.3)$ & Useful & $7(41.2)$ \\
\hline Sign language only & $0(0)$ & Very useful & $5(29.4)$ \\
\hline Oral \& sign language & $5(21.7)$ & \multicolumn{2}{|l|}{ Sounds Required } \\
\hline \multicolumn{2}{|l|}{ Member of Deaf Community } & Clock & $12(52.2)$ \\
\hline Yes & $5(21.7)$ & Oven & $11(47.8)$ \\
\hline No & $18(78.3)$ & Baby & $3(13.0)$ \\
\hline \multicolumn{2}{|l|}{ Previous Supports Used } & Mobile & $19(82.6)$ \\
\hline Hearing aids & $23(100)$ & Phone & $15(65.2)$ \\
\hline Cochlear implant & $5(21.7)$ & Door & $22(95.7)$ \\
\hline Hearing loss support group & $0(0)$ & Bell & 21 (91.3) \\
\hline Communication training & $4(17.4)$ & Kettle & $5(21.7)$ \\
\hline Assistive listening devices & $13(56.5)$ & Smoke alarm & $21(91.3)$ \\
\hline Other & $0(0)$ & Get person & $15(65.2)$ \\
\hline
\end{tabular}

Table 3. Mean, median, and standard deviation of Medical Outcomes Survey responses from hearing dogs waitlist cohort $\left(n=21^{*}\right)$ alongside Australian normative data** from most severe to least severe health impairment

\begin{tabular}{|c|c|c|c|}
\hline & Mean (SD) & Median & Normative data mean (SD) \\
\hline Energy/fatigue & $50.0(16.7)$ & 50.0 & $63.9(19.4)$ \\
\hline Pain & $61.9(26.0)$ & 57.5 & $76.9(25.2)$ \\
\hline General health & $66.2(19.6)$ & 65.0 & $71.5(20.8)$ \\
\hline Role limitations due to physical health & $66.7(31.0)$ & 75.0 & $79.7(35.1)$ \\
\hline Social functioning & $69.0(27.3)$ & 75.0 & $84.6(22.2)$ \\
\hline Physical functioning & $69.5(22.5)$ & 75.0 & $83.6(35.1)$ \\
\hline Role limitations due to emotional problems & $69.8(34.8)$ & 66.7 & $83.7(30.9)$ \\
\hline Emotional wellbeing & $71.2(21.2)$ & 80.0 & $75.7(16.4)$ \\
\hline Total score & $65.6(15.2)$ & 66.9 & $77.5(25.6)$ \\
\hline
\end{tabular}

*Missing data from two respondents

**Australian Institute of Health and Welfare [37] 
Table 4. Social Functioning Questionnaire scores for the Australian hearing dogs waitlist cohort $(n=22)^{*}$. Subscale scores are listed from most severe to least severe impairment

\begin{tabular}{lcc}
\hline & $\begin{array}{c}\text { Mean } \\
(S D)\end{array}$ & Median \\
\hline Close relationship difficulties & $1.5(1.1)$ & 1.1 \\
\hline Feeling lonely and isolated from others & $1.5(0.9)$ & 0.9 \\
\hline Stressful work/home tasks & $1.2(0.9)$ & 1.0 \\
\hline No money problems & $0.8(0.6)$ & 1.0 \\
\hline Getting on well with family & $0.7(0.6)$ & 1.0 \\
\hline $\begin{array}{l}\text { Satisfactory completion of work/home } \\
\text { tasks }\end{array}$ & $0.4(0.7)$ & 0.0 \\
\hline Enjoyment of spare time & $0.3(0.5)$ & 0.0 \\
\hline Total score & $6.5(3.7)$ & 6.5 \\
\hline
\end{tabular}

*Missing data from one respondent

Table 5. Pet Expectation Inventory scores for an Australian hearing dogs waitlist cohort $(n=23)$. Statements are listed from highest to lowest agreement on a 7-point Likert-type scale

\begin{tabular}{lll}
\hline & $\begin{array}{c}\text { Mean } \\
\text { (SD) }\end{array}$ & Median \\
\hline A companion & $6.6(0.8)$ & 7.0 \\
\hline A living thing to love & $6.5(0.8)$ & 7.0 \\
\hline Should always be there & $6.1(1.0)$ & 6.0 \\
\hline Something to talk to & $6.1(1.6)$ & 7.0 \\
\hline Something to love & $6.1(1.2)$ & 7.0 \\
\hline $\begin{array}{l}\text { Make owner feel better when sad or } \\
\text { discouraged }\end{array}$ & $5.8(1.2)$ & 6.0 \\
\hline There to protect & $5.7(1.5)$ & 6.0 \\
\hline There to stroke and cuddle & $5.6(2.1)$ & 6.0 \\
\hline An interesting topic for conversation & $5.7(1.5)$ & 6.0 \\
\hline Able to play with hearing dog & $5.4(1.8)$ & 6.0 \\
\hline Be a source of laughter & $5.2(1.7)$ & 5.0 \\
\hline Confide in their hearing dog & $4.4(2.5)$ & 5.0 \\
\hline Able to teach their hearing dog tricks & $4.0(2.0)$ & 4.0 \\
\hline Total score & $73.1(10.9)$ & 73.0 \\
\hline
\end{tabular}

time being the least affected. Figure 1 displays the distribution of responses for each SFQ item. The higher the score, the poorer the reported social functioning.

\section{Pet Expectations Inventory (PEI)}

Table 5 details scores for each PEI question. The total PEI mean score for the 23 respondents was 73.1 ( $\mathrm{Mdn}=73.0$, $\mathrm{SD}=10.9$, range 55-91). Respondents strongly agreed that the hearing dog should be "a companion" and "a living thing to love.” Distributions were generally skewed towards higher scores, except for respondents expecting to "teach their hearing dog tricks" and "confide in their hearing dog" (Figure 2).

\section{SFQ and HHIA comparison}

There was a moderate, positive, linear correlation between total SFQ scores and total HHIA scores $(r=0.703, p=0.023)$. When separated into subscales, there was a moderate, positive, linear correlation between the total SFQ score and respondents' HHIA emotional subscale scores $(r=0.676, p=0.032)$ and their HHIA situational/social subscale scores $(r=0.690, p=0.027)$. In other words, poorer social functioning on the SFQ was associated with higher emotional and social dysfunction on the HHIA.

\section{SFQ and MOS comparison}

There was a moderate, negative, linear correlation between total SFQ scores and total MOS scores $(r=-0.539, p=0.012)$. When separated into MOS subscales, there was a moderate, negative, linear significant correlation between total SFQ score and role limitations due to emotional problems ( $r=-0.546, p=0.010)$, as well as between total SFQ score and energy/fatigue $(r=-0.630, p=0.002)$. A strong, negative, linear correlation was also noted between total SFQ score and emotional wellbeing $(r=-0.733, p=<0.01)$. Collectively, poorer social functioning on the SFQ was associated with lower health scores on the MOS. No further significant correlations between scores were found for any other combination of questionnaires within the survey package.

\section{Discussion}

\section{Demographic Characteristics}

The General Information Survey and the SFQ found that the majority of respondents were female, retired, owned their own house, and reported no significant financial difficulties. This suggests that the demographic seeking a hearing dog is one with financial stability and time to dedicate to pet ownership. Almost all of the respondents had previous pet ownership experience, which demonstrates an understanding of what may be involved with ownership of a hearing dog, including feeding, housing, and caring responsibilities, as well as a general inclination toward animal companionship.

The majority of respondents were tertiary educated (TAFE/ college, 35\%; university, $30 \%$ ). This is higher than the general Australian population where $56 \%$ of Australians, aged 15 years and over, hold a non-school qualification [34]. With this increase in education level, respondents may be more aware of the potential to own a hearing dog and have greater ability to access the service. Furthermore, respondents with higher levels of education are more likely to respond to surveys than those who might struggle with language and literacy barriers.

\section{Audiological Characteristics}

Although most respondents reported a sensorineural hearing loss, a high proportion of respondents were not aware of their type of hearing loss (Did not know, 26\%; Misreported as conductive, 9\%). [Note: The Australian Lions Hearing Dogs waitlist is restricted to those with at least a severe degree of loss. Therefore, it is not possible for the cohort to have a conductive loss alone, as these produce lesser 

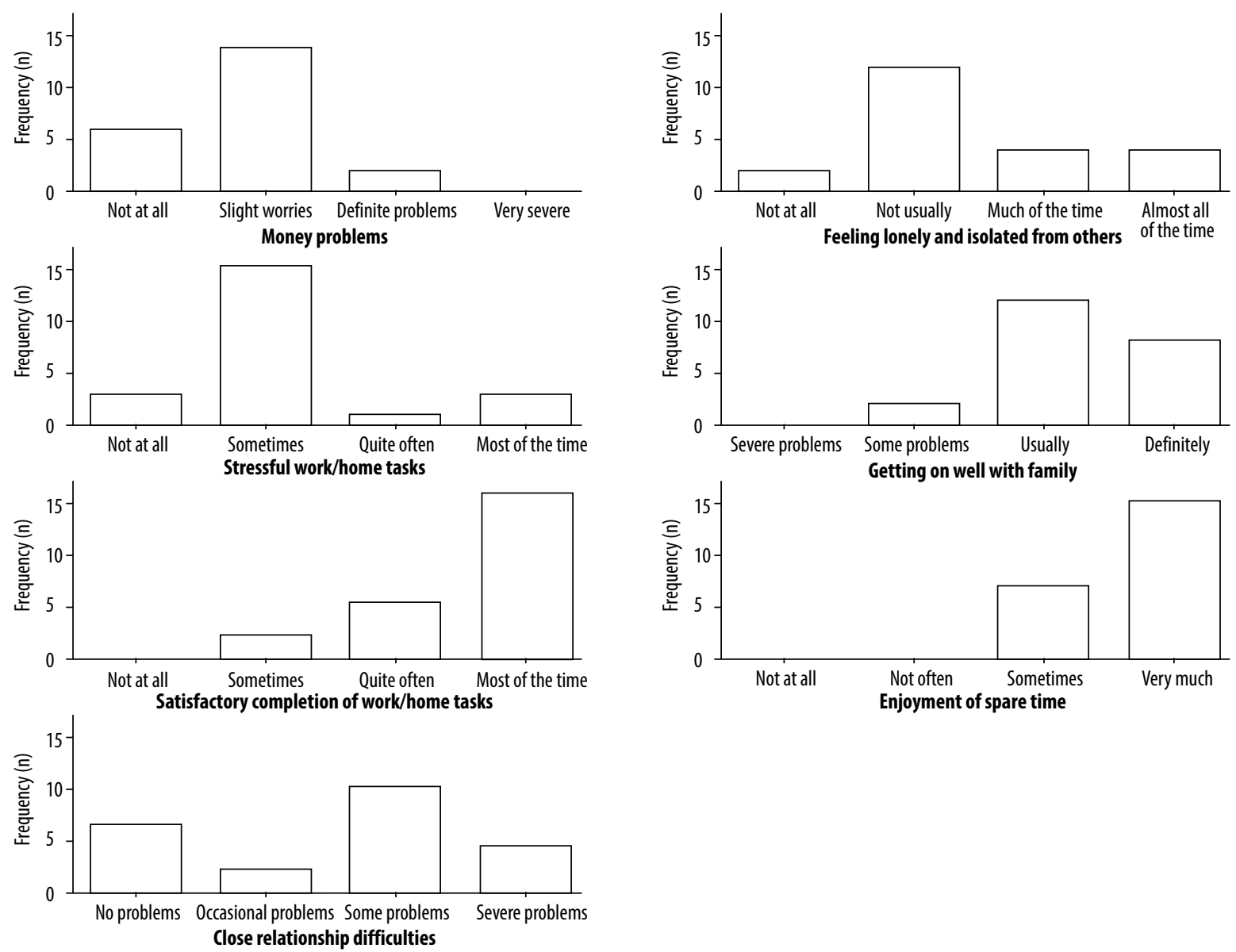

Figure 1. Distribution of Social Functioning Questionnaire responses for an Australian hearing dogs waitlist cohort $(n=22)$


Figure 2. Example of distributions of Pet Expectations Inventory responses for an Australian hearing dogs waitlist cohort $(n=23)$, where 7 indicates strong agreement and 1 indicates strong disagreement on a 7-point Likert-type scale 
degrees of loss.] A small proportion of respondents (9\%) also did not know the degree of their loss. The implication is that recall of the type or degree of loss is not as important or as easy for clients as recall of their activity limitations and participation restrictions. It is possible that audiologists may be failing to impart diagnostic information to clients in a meaningful and memorable way. Alternatively, this finding may reflect the current service trend of focusing on the effects of the hearing loss using a client-centred, solution-based approach rather than a purely diagnostic mindset.

All respondents had previously used hearing aids and over half had used ALDs, highlighting that their needs have not been satisfied by current audiological products and strategies alone, since they are on the waitlist to obtain a hearing dog. Importantly, as the majority of respondents were satisfied, regular users of amplification, the provision of a hearing dog should not be viewed as an alternative to devices or audiological strategies but, instead, as an additional service that might fill a gap in the needs of clients. Hearing dogs provide 24/7 assistance with environmental sounds and companionship, which no current audiological devices can offer. The need for further assistance is also demonstrated by the finding that a large proportion of respondents had had a hearing impairment since birth $(30 \%)$ and yet were still on the hearing dog waitlist because of outstanding needs, despite having had longterm access to audiological services. Additionally, those from the Deaf community in the present study (21.7\%) represent a higher proportion of respondents than is typically found in the hearing-impaired population (approx. $0.4 \%$ ) [35-36]. This overrepresentation suggests that this demographic group, in particular, has needs that have not been addressed by audiology, a likely phenomenon given that audiological rehabilitation has traditionally focused on the provision of amplification devices which are less commonly adopted in the Deaf than in the hearing-impaired population.

\section{Health}

In their MOS scores, respondents reported higher limitations than the general population regarding bodily pain and general health, as well as in other domains such as physical function, role limitations, emotional wellbeing, and social function [29,37]. This finding is unsurprising given that individuals with a hearing impairment are more likely to have co-morbidities such as diabetes, obesity, cardiovascular disease, and cognitive impairments, which negatively affect their health [38-39]. In view of the poor health of the waitlist cohort, there appears to be a vast need for assistance beyond the hearing dogs' notification of environmental sounds.

Respondents reported the most difficulties with energy/ fatigue, that is, they reported feeling tired and worn out all the time [29]. This is consistent with the additional effort and concentration required for hearing-impaired persons when conversing with normal-hearing peers, which depletes their energy resources and leads to fatigue and an increased need for recovery after these interactions [40-41]. A hearing dog could provide support to reduce this fatigue, by encouraging physical exercise and social interaction, as human interactions with friendly dogs have been found to release endorphins and help with the reduction of common fatigue-related symptoms, such as depression and anxiety symptoms [42-43]. Additionally, a hearing dog can assist with alleviation of additional listening effort by being present for a hearing-impaired person's conversation with a normal-hearing peer. For example, if a hearing-impaired person with a hearing dog is communicating with a normal-hearing peer, because the peer has an ability to observe the hearing dog with their "Australian Lions Hearing Dog" jacket, it may allow them to consciously or subconsciously employ communication strategies to effectively communicate with the hearing-impaired person, reducing the additional listening effort for the hearingimpaired person and in turn reducing fatigue [40].

An important aspect of health is physical health. Multiple studies show evidence that physical activity decreases an individual's risk of chronic illnesses such as diabetes, cardiovascular disease, obesity, and chronic pain [44-46]. MOS scores confirm that respondents experienced higher limitations with physical health than the general population, placing the waitlist cohort at greater risk of developing a chronic illness. By obtaining a hearing dog, this risk could be reduced by the necessity of fulfilling the dog's daily exercise requirements. Additionally, an owner's participation in exercise could be a contributing factor to increased socialisation and emotional functioning, as there is a synergistic and intertwined relationship between health, social functioning, and emotional functioning (see Figure 3). Therefore, the influence of hearing dog ownership may not be singular, as often an alteration in health will affect an individual's social and emotional functioning (and vice versa).

\section{Social Functioning}

Social functioning and social connections have an impact on an individual's general health, with an increase in socialisation showing positive effects on general health [47-50]. Hearing-impaired individuals often experience strained relationships due to difficulties with communication, resulting in social withdrawal, loneliness, and poorer mental health [51-52]. The ability to engage in social functions can be impaired due to the additional communication effort required. Consistent with this notion, the respondents from this study had difficulties within the social realm, as evidenced by high SFQ scores regarding relationship difficulties and social isolation, as well as total SFQ scores when compared to the general population. The total SFQ scores were substantially greater than those of the general population, with respondents reporting a mean score of 6.5 , as compared to the general population mean score of 4.6 , and $32 \%$ of respondents reporting a score of $\geq 9$, whereas only $10 \%$ of the general population reports the equivalent [30]. This disparity highlights the vast difference between the social functioning of the respondents as compared to the general population. Furthermore, respondents with poorer social functioning more frequently reported feeling tired and worn out all the time. Limitations with social functioning were also evident from MOS scores, with respondents reporting a substantially lower score on the social functioning subscale than the normative data (see Table 3). Furthermore, the social limitations of respondents are 

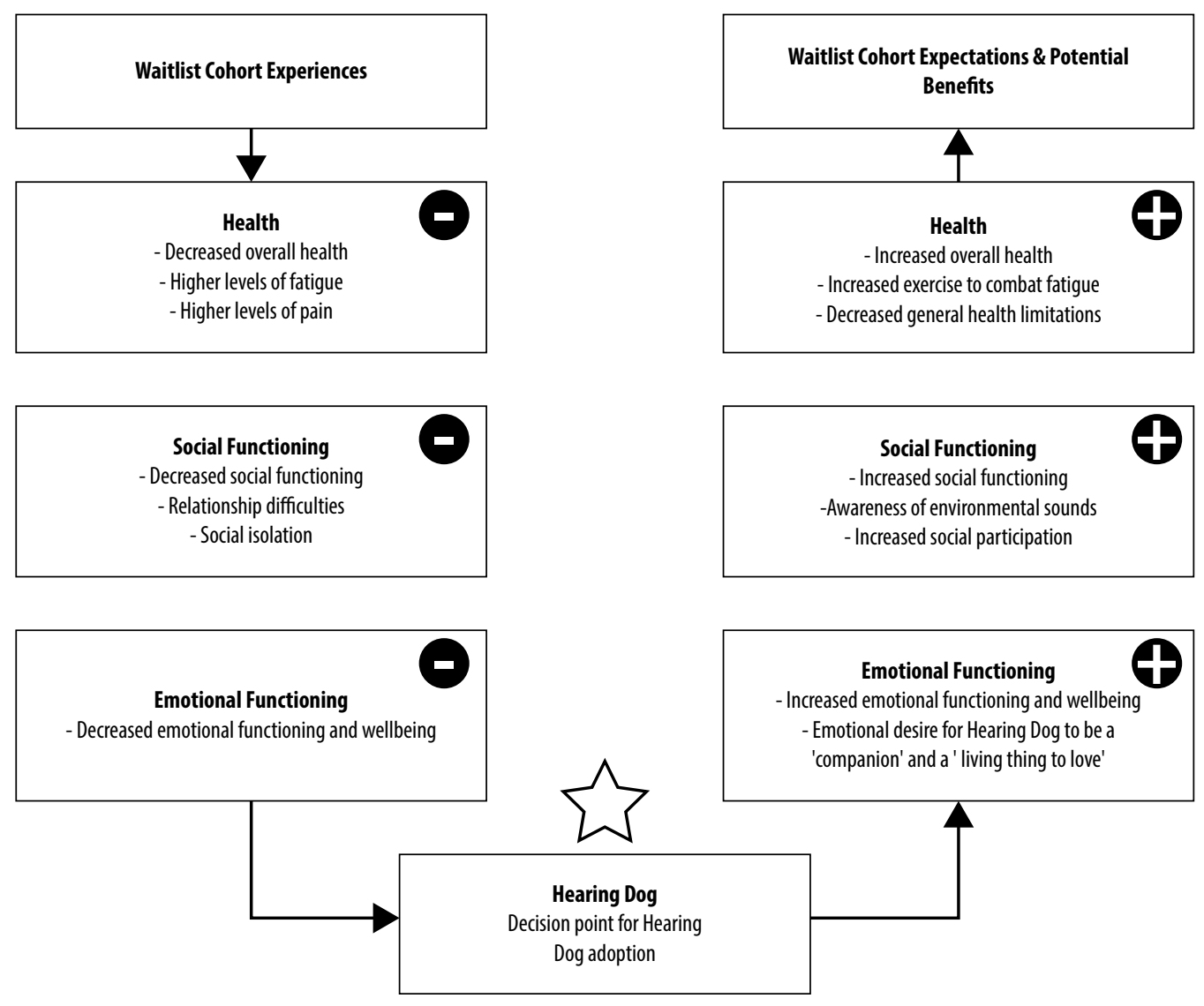

Waitlist Cohort Expectations \& Potential Benefits
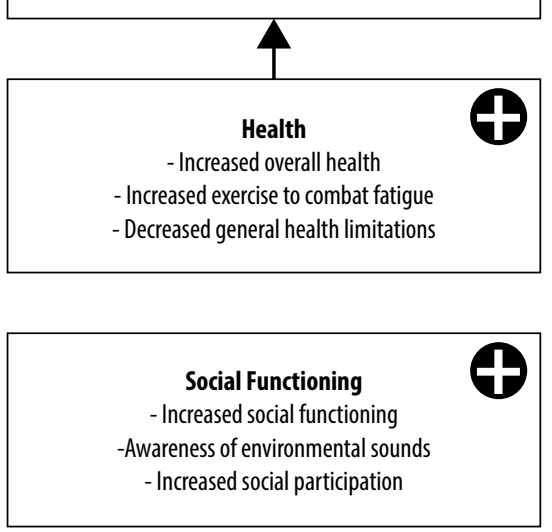

- Increased social functioning

wareness of environmental sound

- Increased social participation

reased emotional functioning and wellbeing

- Emotional desire for Hearing Dog to be a

'companion' and a ' living thing to love'

Figure 3. Flowchart highlighting the synergistic relationship between emotional functioning, social functioning, and health as observed in the experiences and expectations of an Australian hearing dogs waitlist cohort

consistent with the generally reduced welfare of the hearing-impaired population, which as a group have social difficulties, diminished quality of life, reduced employment, and increased mental health difficulties [1].

SFQ scores highlight the social limitations of the waitlist cohort, and while quality of life was not explored directly in the study, SFQ scores have been found to correlate well with quality of life measures [30], i.e., low SFQ scores correlate with a low quality of life. Hearing dogs increase the socialisation and subsequent wellbeing of their owners through re-engagement with society, due to increased confidence and independence $[6,8,19]$. This increase in socialisation and wellbeing has been linked to an overall increase in quality of life $[12,53]$. Therefore, it is hoped that future hearing dog recipients would experience a decrease in social limitations and a subsequent increase in their quality of life.

Respondents, regardless of age, reported poor social functioning via the HHIE/HHIA measures. Interestingly, respondents who were 65 years or older reported greater limitations with situational/social functioning than respondents under 65 years, which is a pattern also observed in normative data [24]. Nevertheless, all respondents are likely to experience communication difficulties, as a result of the severity of their hearing impairments, along with outstanding needs that have not yet been met by audiology, placing them at an increased risk of social isolation and loneliness $[24,54]$. Furthermore, communication difficulties have been found to be a significant predictor of smaller social networks and fewer positive exchanges, which can result in less frequent social participation and higher levels of loneliness [54]. This social functioning effect could be mitigated by a hearing dog, which can provide companionship to their owner, encouraging them to participate in more social events with increased confidence and independence [9]. Adoption of a hearing dog may be particularly useful, since an increase in participation in clubs, classes, and organised activities has been found to assist older adults with their memory and cognitive function, with follow-on effects on their ability to live independently [55]. Additionally, as healthy older adults have increased involvement in social contexts and social network connections, hearing dog ownership could promote a synergy between physical health and social participation $[11,56]$.

There was a strong correlation between SFQ scores and HHIA scores, with respondents that reported higher social functioning limitations also evidencing a higher HHIA total score. This suggests that respondents under the age 
of 65 years, who have social functioning limitations, will also have perceived situational/social and emotional limitations associated with their hearing loss. This link provides an insight into the complexity of social functioning limitations, in terms of how these limitations become intertwined with an individual's perceived emotional limitations. The current audiological landscape provides some solutions to address the social functioning limitations, such as hearing devices and ALDs, but the emotional limitations are often deeply embedded and harder to address. It is to be hoped that a hearing dog would tackle both the social and emotional limitations by alerting owners not only to environmental sounds but also by providing companionship and comfort to ease emotional anxieties. Furthermore, a high SFQ score in the waitlist cohort, representing poor social functioning, corresponded to a low MOS score, representing poor health. This relationship between social function and health was most notable for the MOS subscale scores of energy/fatigue, emotional wellbeing, and role limitations due to emotional problems. Such complexities emphasise the need for a holistic approach to enhance respondents' social functioning, as the effects of poor social functioning can have debilitating effects on an individual's general and mental health (and vice versa). A hearing dog may provide this holistic approach through the practicality of alerting owners to environmental sounds they need access to, but also through decreasing social functioning limitations through daily interactions with the hearing dog and increasing confidence to attend social functions with the hearing dog's support.

\section{Emotional Wellbeing}

Emotional wellbeing is an important area to explore because, if an individual is emotionally content, they are more likely to cope with life's challenges - such as living with a hearing impairment [57]. It has been found that adults who are hearing-impaired are more likely, as a direct result of their hearing impairment, to experience emotional distress with subsequent social restrictions [58]. Unsurprisingly, this was also evident in the current respondents, as they reported an emotional desire for a hearing dog to help them "feel better," be "a companion," "a living thing to love," and something to "confide in." However, during the MOS survey, when directly asked if they had problems with work or other daily activities as a result of emotional problems in the last 4 weeks, most responded in the negative. Additionally, emotional wellbeing was the least severe limitation reported on the MOS, with a mean score of 71.2. Although respondents scored emotional wellbeing as their least severe limitation, this score was below the normative data mean score of 75.7, suggesting that respondents have greater emotional wellbeing limitations than the general population [37]. This is reinforced by respondents highlighting a clear need for additional emotional support on other measures, such as the HHIE/HHIA, where respondents reported high emotional limitations. Additionally, respondents under 65 years reported higher emotional functioning limitations than respondents who were 65 years or older, which follows a similar pattern to normative data [26]. A potential reason for the younger age group to emphasise emotional limitations as opposed to situational/social limitations could be because they are more recently retired or still of working age and, therefore, have previously established (and still active) social groups, but due to communication difficulties associated with their hearing impairment, they feel a lack of depth in relationships and conversation.

\section{Expectations of a Hearing Dog Waitlist Cohort}

The expectations of respondents were evidenced throughout the responses of the PEI and Hearing Information survey. Hearing dogs primarily provide support with environmental sounds, such as the sound of a doorbell, smoke alarm, or oven timer [12]. This is consistent with respondents reporting a need for their hearing dog to alert them, in particular, to the sounds of a door-knock, doorbell, or smoke alarm. However, although a baby cry is a standard trained sound for hearing dogs [5], it was the least reported sound that respondents required assistance with. Therefore, it may not be beneficial to continue training hearing dogs to this sound, or to some other less frequently sought sounds, and instead provide them as optional sounds available on request.

All PEI scores were generally very high. This suggests that recipients expect much more than their hearing dog to simply provide an alert to environmental sounds. For example, recipients have expectations for their hearing dog to "always be there," "to talk to dog," for the hearing dog "to make recipient feel better when sad or discouraged," "to stroke and cuddle dog," "dog to love recipient," "to play with dog," and "dog to protect recipient." While companion dogs can provide these traits, they are at a disadvantage compared with hearing dogs, which are additionally trained in the practicalities of alerting owners to environmental sounds in a safe and controlled manner and can attend public areas and events where companion animals are prohibited. A recent study found that individuals placed a strong emphasis on the companionship and love that their Service or Hearing Assistance Dog provided, resulting in an increase in their wellbeing and ability to thrive [6]. This is consistent with the current study which found that respondents strongly expected that the hearing dog be "a companion" and "a living thing to love." Accordingly, the expectations of hearing dog ownership extend further than assistance with environmental sounds, to emotional support that increases the recipient's wellbeing and socialisation. Owners have previously reported that the ability of the hearing dog to provide love is evidenced through their constant devotion to their owner during their daily lives, whereas pure animal companionship is linked to engaging in social activities, rather than providing consistent devotion and support to their owner [6]. While hearing dogs provide assistance beyond a companion dog, the expectations reported by respondents in the current study are similar to those attributes seen in companion animals, which - despite its attendant benefits - may result in difficulties for recipients. For instance, owners might experience reluctance to retire their hearing dog, or be unwilling to treat them as a working animal rather than a companion.

\section{Clinical Recommendations}

Australian clients who currently desire a hearing dog include individuals who report more severe health limitations than 
the general population, which are likely to be influenced by other co-morbidities associated with hearing loss, resulting in poor general health, bodily pain, and difficulties with energy/fatigue. Social functioning is a difficulty within this population as they present with relationship difficulties and social isolation, with greater social limitations than those of the general population. Moreover, the potential owners presented with poor HHIE/HHIA scores. Audiologists should be aware of these particular types of clients and consider referral to a hearing dog provider.

With the addition of a hearing dog, these individuals can have the practical benefits of notifications of environmental sounds in a safe and controlled manner, but also have the advantages of companionship (social and emotional support) that hearing dogs can provide. Importantly, hearing dogs and companion dogs are not interchangeable, as hearing dogs are trained to alert owners to environmental sounds in a safe and controlled manner, in addition to attendance in public spaces and events [6]. Additionally, hearing dogs provide assistance $24 / 7$, which extends beyond the limitations of currently available ALDs.

Lastly, while audiologists may routinely provide HHIE/ HHIA questionnaires to clients to consider the effects of their hearing loss, they should also branch out with the provision of other questionnaires, such as the MOS and SFQ, to further understand the health and socio-emotional functioning of clients. Consequently, the provision of these questionnaires will likely provide information that highlights the need for additional services beyond audiology, including hearing dogs. Audiologists will need to be prepared to make a range of referrals to other disciplines if wishing to holistically (and successfully) address the needs of clients.

\section{Limitations}

Although there are many benefits of utilising a postal survey method, including the ability to gather a higher representativeness of the entire population and the lower cost as compared to other alternatives, there are inherent limitations [59]. These include respondents misunderstanding questions, having various interpretations of each question, the inability to explore causal inferences, and a requirement of an average adult literacy level [59]. Additionally, Kelley and colleagues [60] found that postal surveys generate low response rates, approximately $20 \%$, depending on the content and the length of the questionnaires. However, a response rate of $53 \%$ was achieved, which provided sufficient representation of the Australian Hearing Dog waitlist cohort.

A further limitation was the total length of the questionnaires which, even though chosen for brevity, may have seemed overly long to some participants. This likely contributed to a non-response level of $47 \%$ and the missing data rate in some surveys (such as the HHIE/HHIA), which had the most questions for completion. The size of surveys has been found to influence the rate of response, as shorter surveys have higher response rates [61-62].

Another limitation was a small absolute (but not relative) sample size, preventing the investigation of relationships between demographic variables and survey scores. This study was population-based and the small sample size is reflective of the small population of adults with severe/ profound hearing loss who desire a hearing dog in Australia [6].

Lastly, there were large variations in respondents' perceived difficulties and disabilities, as observed in the large standard deviations of MOS scores. This is to be expected due to an inherent bias and subjectivity in an individual's understanding of their own limitations and difficulties.

\section{Future Directions}

Future research should focus on a qualitative approach to understanding the needs that individuals hope a hearing dog will meet, as well as exploration of what it means for a hearing dog to be "a companion" and "a living thing to love." Additionally, it would be useful to follow the current waitlist cohort over time, to determine if expectations of their hearing dog vary post-adoption. Finally, it would be beneficial to compare the waitlist cohort with a casematched cohort of current hearing dog owners, to investigate the effects of hearing dogs on the parameters examined with the present study.

\section{Conclusion}

This novel, population-based study explored the demographic and audiological characteristics of an Australian waitlist cohort with the intention of informing audiological practice on which clients might desire a hearing dog and what they expect to gain from it. The majority of respondents were female, 65 years or older, owned their own house, retired, financially stable, and had previous pet ownership experience. Additionally, most respondents were regular users of devices, highlighting the additional need which is to be filled by a hearing dog over and above current audiological services and devices. Health limitations for respondents were higher than the general population, with respondents reporting difficulties with bodily pain and general health, and substantial social and emotional functioning limitations, which could be alleviated through obtaining a hearing dog. All respondents strongly agreed that they desired their hearing dog to be "a companion" and "a living thing to love," and to detect at least three common environmental sounds. Finally, a hearing dog is not to be viewed as a replacement for current audiological services and solutions, but rather an additional option that should be explored where possible and if applicable to the individual client. Potential recipients are likely to have social, emotional, and health limitations and may expect their hearing dog to not only assist with environmental sounds, but to improve their holistic health status.

\section{Acknowledgements}

The authors thank Australian Lions Hearing Dogs and CEO Mr David Horne for assistance and support. We also thank the participants for their generous time and sharing of insights. 


\section{PET EXPECTATIONS INVENTORY}

Please answer the following questions about the role you expect the hearing dog to take in your life by circling the appropriate number (1-7) next to each question. Please complete all items. Do not leave questions unanswered.

\begin{tabular}{|c|c|c|c|c|c|c|c|c|}
\hline & & 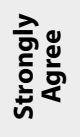 & & & & & & 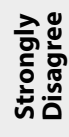 \\
\hline A. & I expect the dog to be a companion for me. & 7 & 6 & 5 & 4 & 3 & 2 & 1 \\
\hline B. & I expect the dog always to be there for me. & 7 & 6 & 5 & 4 & 3 & 2 & 1 \\
\hline C. & l expect to talk to my dog. & 7 & 6 & 5 & 4 & 3 & 2 & 1 \\
\hline D. & $\begin{array}{l}\text { I expect my dog to make me feel better when I am sad } \\
\text { or discouraged. }\end{array}$ & 7 & 6 & 5 & 4 & 3 & 2 & 1 \\
\hline E. & I expect to stroke and cuddle my dog. & 7 & 6 & 5 & 4 & 3 & 2 & 1 \\
\hline F. & I expect my dog to love me. & 7 & 6 & 5 & 4 & 3 & 2 & 1 \\
\hline G. & I expect my dog to be a source of laughter. & 7 & 6 & 5 & 4 & 3 & 2 & 1 \\
\hline $\mathrm{H}$. & $\begin{array}{l}\text { I expect my dog to be an interesting topic of } \\
\text { conversation with friends and relatives. }\end{array}$ & 7 & 6 & 5 & 4 & 3 & 2 & 1 \\
\hline I. & I expect to play with my dog. & 7 & 6 & 5 & 4 & 3 & 2 & 1 \\
\hline J. & I expect my dog to protect me. & 7 & 6 & 5 & 4 & 3 & 2 & 1 \\
\hline K. & I expect to teach my dog tricks. & 7 & 6 & 5 & 4 & 3 & 2 & 1 \\
\hline L. & I expect to confide in my dog. & 7 & 6 & 5 & 4 & 3 & 2 & 1 \\
\hline M. & I expect my dog to be a living thing for me to love. & 7 & 6 & 5 & 4 & 3 & 2 & 1 \\
\hline
\end{tabular}

\section{References}

1. Hearing Care Industry Association. The social and economic cost of hearing loss in Australia. Canberra, Australia; 2017.

2. Hogan A, O'Loughlin K, Davis A, Kendig H. Hearing loss and paid employment: Australian population survey findings. Int J Audiol, 2009; 48(3): 117-22.

3. Grenness C, Hickson L, Laplante-Lévesque A, Davidson B. Patient-centred care: a review for rehabilitative audiologists. Int J Audiol, 2014; 53(1): 60-7.

4. Boisvert I, Clemesha J, Lundmark E, Crome E, Barr C, McMahon CM. Decision-making in audiology: balancing evidence-based practice and patient-centered care. Trends Hear, 2017; 21: 1-14.

5. Australian Lions Hearing Dogs. About Australian Lions Hearing Dogs. 2017. Retrieved 15 October 2019 from https://hearingdogs.asn.au/about-us/

6. Gravrok J, Howell T, Bendrups D, Bennett P. Thriving through relationships: assistance dogs' and companion dogs' perceived ability to contribute to thriving in individuals with and without a disability. Disabil Rehab Assistive Tech, 2019; 1(1): 1-8.
7. Bergin B. Companion animals for the handicapped. In: Edney BFA (Ed.), Interrelations between people and pets. Springfield, IL: Charles C. Thomas; 1981, 191-236.

8. Audrestch HM, Whelan CT, Grice D, Asher L, England GCW, Freeman SL. Recognizing the value of assistance dogs in society. Disabil Health J, 2015; 8(4): 469-74.

9. Guest CM, Collis GM, McNicholas J. Hearing dogs: A longitudinal study of social and psychological effects on deaf and hard-of-hearing recipients. J Deaf Studies Deaf Ed, 2006; 11(2): $252-61$.

10. Hall S, Macmichael J, Turner A, Mills D. A survey of the impact of owning a service dog on quality of life for individuals with physical and hearing disability: a pilot study. Health QOL Outcomes, 2017; 15(1): 59-68.

11. Hart LA, Zasloff RL, Benfatto AM. The socializing role of hearing dogs. Appl Anim Behav Sci, 1996; 47(1-2): 7-15. 
12. Lundqvist M, Levin L-A, Roback K, Alwin J. The impact of service and hearing dogs on health-related quality of life and activity level: a Swedish longitudinal intervention study. BMC Health Serv Res, 2018; 18(1): 497-506.

13. Valentine D, Kiddoo M, Lafleur B. Psychosocial implications of service dog ownership for people who have mobility or hearing impairments. Soc Work Health Care, 1993; 19(1): 109-25.

14. Furuta S, Nakamura T, Iwahori Y, Fukui S, Kanoh M, Yamada K. Consideration of life rhythm for hearing-dog robots searching for user. In: Lee R (Ed.), Computational science/Intelligence and applied informatics (Vol. 726). Cham: Springer International Publishing; 2018, 102-5.

15. Yoshida Y, Sekiya D, Nakamura T, Kanoh M, Yamada K. Hearing-dog robot to wake people up using its bumping action. In Lee R (Ed.), Computational science/Intelligence and applied informatics (Vol. 726). Cham: Springer International Publishing; 2018: 41-50.

16. Bert F, Gualano MR, Camussi E, Pieve G, Voglino G, Siliquini R. Animal assisted intervention: a systematic review of benefits and risks. Eur J Integr Med, 2016; 8(5): 695-706.

17. Sadler M. I Came Alive the Day I Got Teddy. 2018. Retrieved 15 October 2019 from https://www.hearingdogs.org.uk/ helping-deaf-people/stories/vincent-and-teddy/

18. White N, Mills D, Hall S. Attachment style is related to quality of life for assistance dog owners. Int J Envir Res Pub Health, 2017; 14(6): 658-66.

19. Sachs-Ericsson N, Hansen NK, Fitzgerald S. Benefits of assistance dogs: a review. Rehab Psychol, 2002; 47(3): 251-77.

20. Shafer DN. A Tail of Hearing Service: Service Dogs Can Fill Gaps For People With Hearing Loss. 2005. Retrieved 15 October 2019 from https://leader.pubs.asha.org/doi/full/10.1044/ leader.FTR6.10032005.4

21. Calnan M. Quantitative survey methods in health research. In: Saks M, Allsop J (Eds.), Researching Health: Qualitative, quantitative and mixed methods (2nd ed.). London: SAGE; 2013.

22. Greasley AE, Fulford RJ, Pickard M, Hamilton N. Help musicians UK hearing survey: musicians' hearing and hearing protection. Psych Mus, 2018; 27(1): 1-18.

23. Raj-Koziak D, Gos E, Rajchel J, et al. Tinnitus and hearing survey: a Polish study of validity and reliability in a clinical population. Audiol Neurotol, 2018; 22(4-5): 197-204.

24. Ventry MI, Weinstein EB. The hearing handicap inventory for the elderly: a new tool. Ear Hear, 1982; 3(3): 128-34.

25. Aiello CP, Lima II, Ferrari DV. Validity and reliability of the hearing handicap inventory for adults. Brazil J Otorhinolaryn, 2011; 77(4): 432-38.

26. Newman WC, Weinstein EB, Jacobson PG, Hug AG. The hearing handicap inventory for adults: psychometric adequacy and audiometric correlates. Ear Hear, 1990; 11(6): 430-3.

27. Newman WC, Weinstein EB, Jacobson PG, Hug AG. Test-retest reliability of the hearing handicap inventory for adults. Ear Hear, 1991; 12(5): 355-7.

28. Saccone PA, Steiger JR. Hearing handicap among adult residents of an urban homeless shelter. J Health Care Poor Underserved, 2007; 18(1): 161-72.

29. Ware JE, Sherbourne CD. The MOS 36-item short-form health survey (SF-36). I. Conceptual framework and item selection. Med Care, 1992; 30(6): 473-83.

30. Tyrer P, Nur U, Crawford M, et al. The social functioning questionnaire: a rapid and robust measure of perceived functioning. Int J Soc Psych, 2005; 51(3): 265-75.

31. Blount C, Evans C, Birch S, Warren F, Norton K. The properties of self-report research measures: beyond psychometrics. Psych Psychotherap Theory, Res, Prac, 2002; 75(2): 151-64.
32. Kidd AH, Kidd RM, George CC. Veterinarians and successful pet adoptions. Psychol Reports, 1992; 71: 551-7.

33. Demorest ME, Walden BE. Psychometric principles in the selection, interpretation, and evaluation of communication selfassessment inventories. J Speech Hear Dis, 1984; 49(3), 226.

34. Australian Bureau of Statistics. 2016 Census Quickstats. 2016. Retrieved 15 October 2019 from https://quickstats.censusdata.abs.gov.au/census_services/getproduct/census/2016/ quickstat/036

35. Australian Institute of Health and Welfare. Australia's Health 2016. 2016. Retrieved 15 October 2019 from https://www.aihw. gov.au/getmedia/48ee92a8-d373-4354-8df2-d664a974034f/ ah16-3-15-vision-hearing-disorders.pdf.aspx

36. Deaf Australia Inc. Annual Report 2017-2018. 2017. Retrieved 15 October 2019 from https://deafaustralia.org.au/wp-content/ uploads/Annual-Report-2017-18-1.pdf

37. Australian Institute of Health and Welfare. SF-36 interim norms for Australian data. 1996. Retrieved 15 October 2019 from https://www.aihw.gov.au/reports/corporate-publications/ sf-36-interim-norms-for-australian-data/contents/summary

38. Besser J, Stropahl M, Urry E, Launer S. Comorbidities of hearing loss and the implications of multimorbidity for audiological care. Hear Res, 2018; 369, 3-14.

39. Dhanda N, Taheri S. A narrative review of obesity and hearing loss. Int J Obesity, 2017; 41(7), 1066-73.

40. Alhanbali JS, Dawes JP, Lloyd JS, Munro JK. Self-reported listening-related effort and fatigue in hearing-impaired adults. Ear Hear, 2016; 38(1): e39-48.

41. Nachtegaal J, Festen JM, Kramer SE. Hearing ability in working life and its relationship with sick leave and self-reported work productivity. Ear Hear, 2012; 33(1): 94-103.

42. Herring MP. Exercise for the management of anxiety and stressrelated disorders. In: Stubbs B, Rosenbaum S (Eds.), Exercisebased interventions for mental illness: physical activity as part of clinical treatment. UK: Academic Press; 2018: 19-52.

43. Schuch FB, Dunn AL, Kanitz AC, Delevatti RS, Fleck MP. Moderators of response in exercise treatment for depression: a systematic review. J Affect Dis, 2016; 195: 40-9.

44. Geneen LJ, Moore RA, Clarke C, Martin D, Colvin LA, Smith BH. Physical activity and exercise for chronic pain in adults: an overview of Cochrane reviews. Cochrane Database Systematic Rev, 2017; 4: 1-76.

45. Penedo FJ, Dahn JR. Exercise and well-being: a review of mental and physical health benefits associated with physical activity. Curr Opin Psych, 2005; 18(2): 189-93.

46. Warburton DER, Nicol CW, Bredin SSD. Health benefits of physical activity: the evidence. Can Med Assoc J, 2006; 174(6): 801-9.

47. Gilbert KL, Quinn SC, Goodman RM, Butler J, Wallace J. A meta-analysis of social capital and health: a case for needed research. J Health Psych, 2013; 18(11): 1385-99.

48. Holt-Lunstad J, Smith T, Layton J. Social relationship and mortality risk: a meta-analytic review. PLoS Med, 2010; 7(7): 1-20.

49. Jordan S, Diederichs CD, Dollmann SD, Neuhauser HN. Health literacy, general health and social support. Results from the survey 'German Health Update'. Eur J Pub Health, 2017; 27(Suppl. 3).

50. Uchino BN. Understanding the links between social support and physical health: a life-span perspective with emphasis on the separability of perceived and received support. Pers Psychol Sci, 2009; 4(3): 236-55.

51. Hyams A, Margolius V, Scogin F, Hay-McCutcheon M. Hearing loss is uniquely associated with social functioning among older adults. Gerontol, 2015; 55: 447. 
52. Packer L. The Impact of Hearing Loss on Relationships. 2017. Retrieved 15 October 2019 from https://www.healthyhearing.com/ report/52619-The-impact-of-hearing-loss-on-relationships

53. Martellucci S, Belvisi V, Ralli M, et al. Assistance dogs for persons with hearing impairment: a review. Int Tinnitus J, 2019; 23(1): 26-30.

54. Palmer AD, Newsom JT, Rook KS. How does difficulty communicating affect the social relationships of older adults? An exploration using data from a national survey. J Comm Dis, 2016; 62: 131-46.

55. Brustrom J, Greek A, Liu T, Hougham G. Which social activities best predict cognitive functioning in older adults? Gerontol, 2016; 56(Suppl. 3): 370.

56. Cornwell B, Laumann EO, Schumm LP. The social connectedness of older adults: a national profile. Amer Sociol Rev, 2008; 73(2): 185-203.

57. American Academy of Family Physicians. Mental health: keeping your emotional health. 2017. Retrieved 15 October 2019 from https://familydoctor.org/mental-health-keeping -your-emotional-health/
58. Gopinath B, Hickson L, Schneider J, et al. Hearing-impaired adults are at increased risk of experiencing emotional distress and social engagement restrictions five years later. Age Ageing, 2012; 41(5), 618-23.

59. Queiros A, Faria D, Almeida F. Strengths and limitations of qualitative and quantitative research methods. Eur J Ed Stud, 2017; 3(9): 369-86.

60. Kelley K, Clark B, Brown V, Sitzia J. Good practice in the conduct and reporting of survey research. Int J Qual Health Care, 2003; 15(3): 261-6.

61. Liu M, Wronski L. Examining completion rates in web surveys via over 25,000 real-world surveys. Soc Sci Comp Rev, 2018; 36(1): 116-24.

62. Saleh A, Bista K. Examining factors impacting online survey response rates in educational research: perceptions of graduate students. J Multidisc Eval, 2017; 13(29): 63-74. 